\section{DAVID COPPERFIELD AND THE BILDUNGSROMAN: THEIR CONTRIBUTION TO CHARLES DICKENS' $S$ REPUTATION $^{1}$}

\section{Sakchai Lunlaporn ${ }^{2}$}

\section{บทคัดย่อ}

บทความนี้มุ่งวิเคราะห์รูปแบบทางวรรณกรรมของ พัฒนาการของตัวละครที่ชาร์ลส์ ดิกเกนส์นำมาใช้ เพื่อนำเสนอพัฒนาการของตัวละครเอก นวนิยาย เรื่องเดวิด คอปเปอร์ได้สร้างชื่อเสียงให้กับดิกเกนส์ และได้สร้างมุมมองใหม่สำหรับผู้อ่านนวนิยายแนว พัฒนาการตัวละคร โดยมีรูปแบบในการนำเสนอ ผ่านภาพวาดประกอบ การเล่าเรื่องผ่านบุรุษที่หนึ่ง เรื่องราวของวีรบุรุษ และการใช้ชีวิตร่วมกับตัว ละครอื่นเพื่อทำให้เนื้อเรื่องมีความแตกต่างจากนว นิยายเรื่องอื่นในแนวเดียวกัน และเครื่องมือทาง วรรณคดีเหล่านี้มุ่งไปที่การค้นหาตัวตนและอาชีพ ของตัวละคร รูปแบบเหล่านี้ช่วยฟื้นชื่อเสียงและ การยอมรับนวนิยายของดิกเกนส์อีกครั้งโดย ชี้ให้เห็นความสามารถของดิกเกนส์ในการผสาน รูปแบบเหล่านั้นเพื่อช่วยให้ชื่อเสียงของเขาคงอยู่

\footnotetext{
1 เดวิด คอปเปอร์ฟีลด์และวรรณกรรมพัฒนาการตัว ละครในการสร้างชื่อเสียงให้กับชาร์ลส์ ดิกเกนส์ 2 (ศักดิ์ชัย ลุนลาพร) M.A. Student, Department of English, Faculty of Arts, Chulalongkorn University, Bangkok, Thailand
}

\begin{abstract}
This paper aims to analyze the ways in which Charles Dickens employed the literary genre of the Bildungsroman to depict his protagonist's life. David Copperfield successfully enhanced Dickens's reputation and provided a new perspective for readers of Bildungs novels. There are several features such as illustrations, a first-person narrative, heroism and his association with other characters that make this different from other novels in this genre and these literary devices center upon his search for a true identity and his career. These features enliven Dickens's novel and contributed to its favourable reception of this novel and they also indicate Dickens's ability to blend forms and cultivate his reputation in this novel.
\end{abstract}

\section{Introduction}

Of the many beloved characters of Charles Dickens, David Copperfield stands high because of his life that the portrayal of David's life adopts the influence of the Bildungsroman to illustrate it under the environment of the nineteenth century. Many years after the appearance of David, people saw in the depiction of this young boy not only the vision of a miserable life that evoked sympathy but also a life that reflected reality to its readers in the Victorian world. David Copperfield and his life story has also appealed to readers in later centuries as the novel allows them to witness life in the nineteenth century and the way in which David struggles to survive in that society.

This story of a young boy in search of his identity in circumstances familiar to its readers' personal fragmented memories made it more interesting to the serials' 
readership. Dickens's enthusiasm for portraying heroism remained and David is set to pursue adventures in a world his readers were acquainted with to ensure that they would follow the serialization with enthusiasm. The ludicrous incidents occurring to David offer to readers the discovery that they themselves are "something of a Copperfield themselves", displaying "the value of self-denial and patience, quiet endurance of unavoidable ills, strenuous effort against ills remediable" (43). The extent to which David's story penetrated the market depended much, therefore, on Dickens's ability to make his contemporary popular culture accessible to his readers in the form of an autobiographical novel.

When Dickens began writing David Copperfield in 1849 readers would probably have recognized its author as the writer of the story of Mr. Esquire and his Pickwick Club in The Pickwick Papers (1837) or the story of the poor orphan boy in Oliver Twist (1839). Eventually, he was greatly hailed for the success of David Copperfield (1850) and became more successful as a writer. As John Forster, Dickens's close friend and personal biographer put it "Dickens never stood so high in reputation as at the completion of Copperfield" (Forster 2004: 42). Indeed, David Copperfield established Dickens's reputation through the story of the young David which is similar to that of young Oliver in that they are both young boy protagonists whose lives have been deprived of boyhood happiness by fate. However, David is hugely different because he is particularly in search of his true identity to become a grown man, whereas Oliver is simply struggling to survive in circumstances beyond his control in a cruel society and part of the novel's success lies in it employment of many incidents from Dickens's own personal life. This article will examine Dickens's use of the genre of the Bildungsroman as a device to depict that successfully depicts the life of David Copperfield.

\section{David Copperfield and the Victorian Bildungsroman novel}

Prior to his writing of David Copperfield, Dickens had already written seven novels that had earned him a resounding reception and placed his name among Britain's most famous writers. David Copperfield employs the influential German form of the Bildungsroman that became an appropriate device for Dickens's intention to write an autobiographical novel. Generally, the Bildungsroman is, according to Penguin Dictionary of Literary Terms \& Literary Theory (1999), the literary device of dealing with one person's, especially the protagonist's, formative years or spiritual education. David Copperfield's Bildung and autobiography are intermingled together in a form that deviates from its original tradition and from its English early adoption in Fielding, Sterne and Goldsmith. According to this definition, David is going through the process of learning by trial-and-error in his personal experience as the protagonist who is a Victorian man searching for his true character.

With its overt characteristic of a Bildung novel, Dickens absorbed the general notion into his new novel's title. During his search for new ideas for his next novel, the decision to write a new serial came from John Forster's suggestion to 
him to write from his own life experience. $\mathrm{He}$ accepted this advice enthusiastically and was at ease writing this story simply because many events were from his personal first-hand experience. After many attempts at finding a suitable name, he eventually entitled his new work: The Personal History, Adventures, Experience, \& Observation of David Copperfield the Younger of Blunderstone Rookery. (Which He never meant to be Published on any Account), later shortened to The Personal History of David Copperfield, indicating what David would have to provide for his readers in his account of his self-improvement. Ostensibly, Dickens chose this epithet for his novel in order to lay out the entire story for the protagonist to lead his readers to witness his formation within the Victorian concept of self-development. Another reason, Dickens wanted to assert the point at which this story was going to be specifically the personal history of David Copperfield, not Dickens's own history; even though, readers would find analogous references to Dickens's experiences. Therefore, David is employed to narrate the entire novel by adopting the device of first person narrative.

Dickens's insertion of illustrations was, on the one hand, to give them the pleasure of plates as in the other novels; on the other hand, illustrations worked with the author's intention of depicting David's self-development. His intention to include illustrations in each volume was to delight his readers in their reading and make the novel recognizable on stalls and in libraries with the illustration of the front cover that was the same throughout the run in twenty numbers of serialization. Dickens employed Hablot Knight Browne or Phiz, the famous illustrator who had worked with him many times, to illustrate two plates for each volume. The serials with two plates of illustration and advertisements were an illustrated Bildungsroman novel. The relationship between text and illustrations is strongly connected as Stephen Lutman argues on the ground that the tie between text and illustrations are strongly bound:

The illustrations were developed during the course of writing the novels, and having grown with the text can be described as having an organic relationship to it, rather than the more mechanical relationship of illustrations added to a finished work. (1980: 198)

The statement above demonstrates the impact of illustrations on the nineteenth century habit of reading with "a syndrome of related visual and literary forms of which the novel is a part, rather than the historical oddity of a single collaboration between illustrations and fiction" (197). For instance, the apparent clue Phiz used to indicate this process is the depiction of David's legs. In plate four, "The friendly waiter and I," David is sitting on a chair with his legs in the air; whereas, in plate number thirteen, "Somebody turns up," Phiz depicts David on a chair at the Heeps' house, this time his legs are longer and are able to reach the table stretcher. By the time David reaches his mature stage, the illustrations of his physical stature has to be developed accordingly. Phiz thus improved his drawing to depict David with changes in his clothes, in the general aspect of the Victorian middle class man. David's changes in his clothes points to the fact that David as the protagonist is moving towards personal 
betterment. The big change in his clothes comes especially during the time he meets his aunt with ragged clothes and gets to wear new ones after his aunt has accepted him into the house. This is the exercise Dickens conferred on both Phiz and David to preserve David's middle class status in the illustrations as well as to maintain the mutual relationship between the text and illustrations at the same time. The subtlety of Phiz in his illustration is that it can be read complementarily with the text or read separately but never loses touch with the plot of story of the novel. Phiz made it clear in his decision to depict David's development in the said two ways that illustrations had to conform to the market interests that the author cultivated in this way and the significant relationship to its theme of the protagonist's improvement.

Several overt features that emphasize David as the novel of Bildungsroman genre are, as well as the illustrations, the notion in novel of heroism and the development in David use of language and the first-person narrative. Two devices contribute to the protagonist searching after his career as a novelist along the way of his growing in the world. They specifically demonstrate the coherence of David's appropriateness to become a writer through his recalling his memories in letters.

David Copperfield reflects notions of heroism in a common man whose main task is the quest for his identity. Yet, all the features of the work are in accordance with nineteenth-century attitudes and the employment of the Bildungsroman. This novel does not recount the tale from the perspective of a knight or a person from the noble family but that of a middle class man. This notion is declared in David's opening statement that "Whether I shall turn out to be the hero of my own life, or whether that station will be held by anybody else, these pages must show" (1). It, first of all, evokes a sense of heroism where David has to struggle with the dangerous events of his life and conquer them. His heroic mantle is simply adopted that to permit his audience to witness what he encounters and the way he overcomes it. Nevertheless, Dickens differentiates his hero from traditional notions where the hero belongs to a princely class with extraordinarily precocious abilities whose occupation is war or dangerous adventure. Instead Dickens creates David as a hero whose background is that of the common man of the Victorian era from a middle class family. The ultimate achievement of David as a hero is to narrate his life-story and to be capable of self-determination. This expectation is completed by the time David himself finishes the last chapter of his book. The general premise of David as a hero is implied in the statement declaring his personal definition of heroism: "the hero of... pages" (1). In other words, it is seen through this statement that David will resolutely pursue his career as a writer and because he will complete the Bildungsroman novel, the final period when he reaches the stage of life as a writer with his wife demonstrating how he has become a hero in his own way; a hero that brings the pages to life. The intention of Dickens is to create David by defusing the general qualities of hero and, consequently, David as the novelist in the story becomes the hero overcoming obstacles to write these pages. In other words, heroism according to Dickens's definition is about achieving his success in a novelistic career, resulting in his fantasy of placing himself in a position of success that will lead to the firm settling of his life in a way that is more secure than his previous phases in 
the story. Because, David Copperfield is pursuing a writing career that requires the craft of literary skills, the way he presents his narrative implies, concurrently with his physical development, his developing process of crafting his skills in language.

Figure 1: The friendly waiter and I
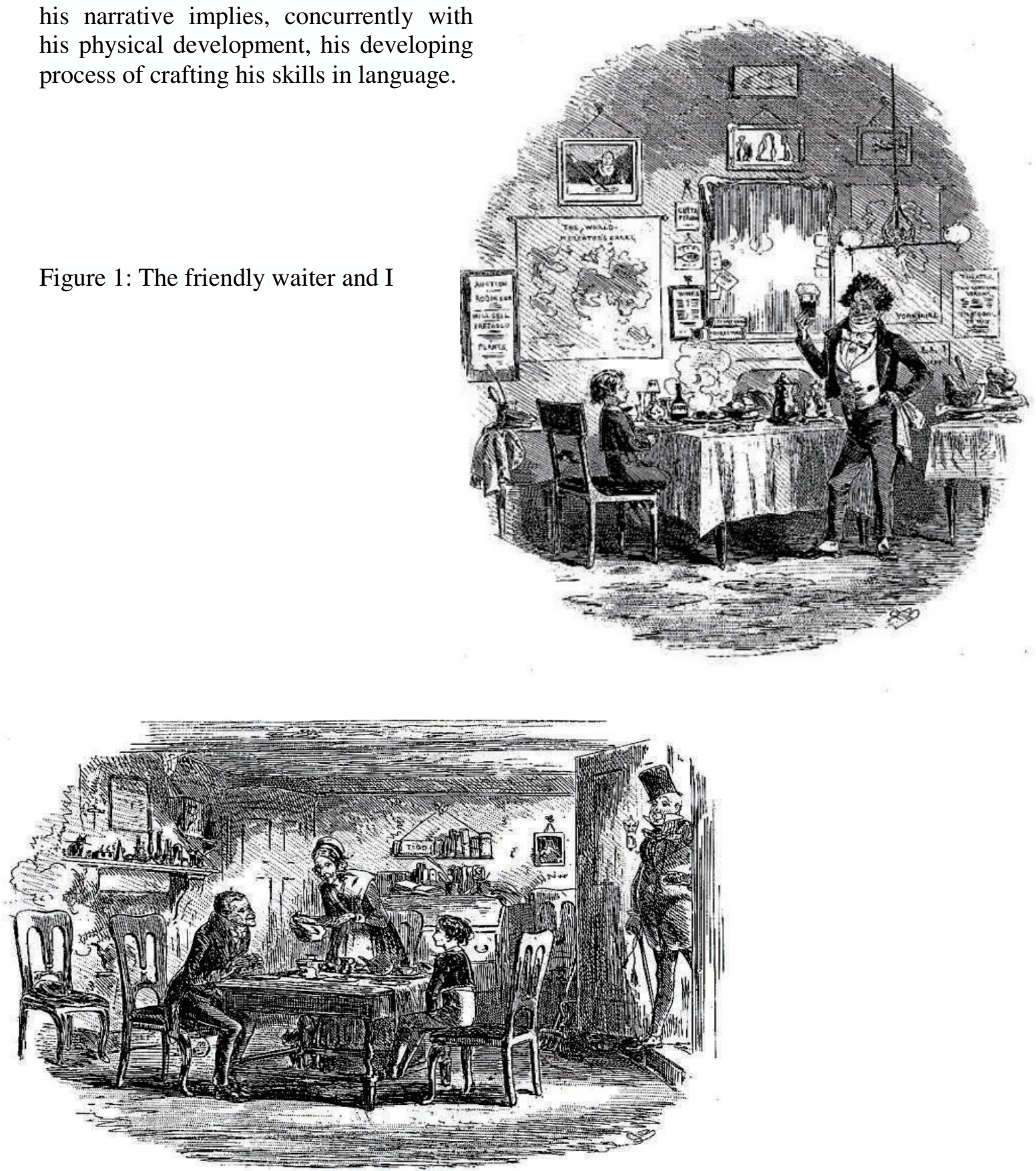

Figure 2: Somebody turns up 
As discussed earlier, David emerges as the hero of his story by being authorized to control the narrative himself and establishing his story up to the direction that can contribute to the Bildungs novel. Implicitly, the narrative technique observes the phases of his growth through the development of his language. This technique resembles the human process of language acquisition. A child is only capable of forming simple sentences before developing the adult ability to articulate its thoughts with a more complex language structure than children. Similarly, the tracing of David use of language is complemented by a serialization that implements the progress of David's growth in one serial, and when the new serial released, David is in another phase of his language development. This technique of language development subtly guides readers to notice each of his phases as being more mature-David himself is conscious of this as well. As a child, he recalls:

I was born at Blunderstone, in Suffolk, or "thereby," as they say in Scotland. I was a posthumous child. My father's eyes had closed upon the light of this world six months, when mine opened on it. There is something strange to me, even now, in the reflection that he never saw me; and something stranger yet in the shadowy remembrance that I have of my first childish associations with his white grave-stone in the churchyard, and of the indefinable compassion I used to feel for it lying out alone there in the dark night,...(2)

This passage demonstrates how David is able to construct simple phrases and sentences as a child. On the other hand, it also shows the process of how David is learning to master the language through his admission of confusion, as says he borrows a word from how English is spoken in Scotland. By detecting how he articulates the death of his father, through associations of words like "closed eyes," "grave-stone," or "churchyard" indicates a reflection of his vague understanding of death. The separation of the graveyard which is being "bolted and locked against" (2) in darkness and the living world seems to suggest that it is far from possible to unite the two worlds together in his mind. The particular changes in his narrative are slight and almost unnoticeable at the more mature stage, however, he subconsciously asserts his confident knowledge of the world as well as the more complex structure of his language as he speaks of his situation: "I know enough of the world now, to have almost lost the capacity of being much surprised by anything" (149). Implicitly, David exerts the more important progress of his growth through his understanding of the world because he was only at the tender age of ten when he was sent to explore it. In the last part, the narrative attempts to mark the mature age of about twenty-eight: "I could not forget that the feeling with which she now regarded me had grown up in my own free choice and course" (797). Another phase of David's language development is seen when he is living with Dora. According to David:

...I will only add, to what I have already written of my perseverance at this time of my life, and of a patient and continuous energy which then began to be matured within me, and which I know to be the strong part of my character, if it have any strength at all, that there, on looking back, I find the source of 
my success...Heaven knows I write this, in no spirit of selflaudation...My meaning simply is, that whatever I have tried to do in life, I have tried with all my heart to do well... (590)

This paragraph marks the difference in David's use of language in terms of its maturity from that which he used when he was a child. The construction of language in this paragraph is becoming more complex with the insertion of David's confidence of his consciousness of life and his inclination to write his life storythe task fully requires literacy skills. Later on, we witness another aspect of his eventual ability to master his use of language. David expresses the sentiment that:

The knowledge came upon me, not quickly, but little by little, and grain by grain. The desolate feeling with which I went abroad, deepened and widened hourly. At first was a heavy sense of loss and sorrow, wherein I could distinguish little else. By imperceptible degrees, it became a hopeless consciousness of all that I had lost-love, friendship, interest; of all that had been shattered-my first trust, my first affection, the whole airy castle of my life; of all that remained-a ruined blank and waste, lying wide around me, unbroken, to the dark horizon. (792-3)

David's expression reminds readers of his resolution to live the rest of his life as a grown man who has experienced the world sufficiently. $\mathrm{He}$ is capable of penetrating into his own mind better than when he was young, and this stage reflects in terms of language complexity that this statement illustrates his capacity of mastering a much more complex structure of language and to express those structures in a more sophisticated way. This passage demonstrates his complex situation and he unravels it into a finely constructed form of language. That Dickens subtly depicts his protagonist's growth through this method suggests his own ingenuity. David himself needs to contribute to both his life and his expected task as a protagonist of this novel of growth. The mastery of language marks the mental structure of the protagonist reaching his maturity when he is capable of mastering language in preparation for his career of writing.

In addition to the subtlety of depicting David's growth through his capacity to master language, a notable feature of David's story is that it is communicated through a first-person narrative throughout the book. This feature implicitly marks the objective of making this the story of David himself, and to distance the author from intervening in David's story. This enterprise differs from that in Bleak House which divides half of the narrative into a first person narrator and gives the other half to a third person narrator. It is similar to Great Expectations in the sense that David Copperfield also relies on Bildungs' conventions and autobiographical elements. The act of turning these pages into equivalent deeds of the hero requires David's careful attention to blend the stories so that they will not confuse his readers. Without any interruptions by a third person narrator, David can freely recall his story from his childhood and make it his own story. In other words, by allowing his protagonist to lead the reader himself through the events in his life story implicitly suggests that he is the "hero of his own life" who independently controls 
his life rather than being under the author's influence. David's first person narration works as a consequence of his identity formation. These three points in generating David maturity contribute to the fact that this is not only a Bildungs novel, but the Bildung of a writer. As such, the language technique that Dickens employed here is distinguished for that particular reason. However, there are various ways of reading this novel as a Bildungs novel such as the way David learns to grow up and discipline himself by associating with other characters.

In keeping with the Bildung's general notion, Dickens allows David to learn to grow up by facing various dilemmas, obstacles, mistakes and conflicts. To "come of age" David inevitably has to set out on a journey in which difficulties and dilemmas are aspects that will shape and improve his character and personality according to the Victorian bourgeois values of self-development. The Bildungsroman of David, the protagonist, is completed by his search for his identity and his maturing into a grown man. However, this novel aims to retell the story of a common young Victorian boy, so, the journey is dismissive of chivalric deeds. Dickens maintains what was similar to the quest of a noble knight in the old sense, but simplified it into the high and low in life that David is questing after. Therefore, David acquiesces to the Victorian social and moral expectation of development. In other words, he is required to discipline himself and discipline his "undisciplined heart" (664), a recurrent theme, when he commits mistakes and learns to remedy them.

Regarding the significance of Bildungsroman in portraying the protagonist's progress in life, it allows the theme of "undisciplined heart" to be supplementarily developed by way of David gaining experiences. David acquires his social education and moulds his self through the crucial process of trial-and-error. This is the crucial element in the Bildungs novel when he is chasing after remedies to his errors when he allegedly commits mistakes. David's mistakes can all be categorised under the theme of "undisciplined heart," whether they be mistakes with his friends or lovers. The "undisciplined heart" is a heart that represents the inexperienced existence of David who is supposed to understand and learn from those who have experienced lives, and also from his own experiences. Carl Bandelin states that David is required to "acquire the ability to live creatively and humanely in the world" (1976: 601). The first incident that marks his misunderstanding over how to judge people tending to misjudge them by their external presentations is presented to him by the Murdstones. When the Murdstones are introduced into David's life, they appear to dislike him from the very start and they also show their intense hatred towards him explicitly. Consequently, he tends to misjudge people by association with whatever appears before his eyes. The explicitness of the Murdstones' hatred of him is associated with his conclusion that what the eyes see is what people intend to do with him. This misunderstanding of people leads David to judge the bad to be good, thereby displaying a lack of profound knowledge of the world. When Mr Murdstone sends him to school in London and he meets such friends as Steerforth and Traddles, he befriends Steerforth, misjudging that all his actions stem from the boy's genuine good intentions. On the other hand, he dislikes Traddles, the clumsy boy from a working- 
class family and completely unlike the upper-middle class Steerforth boy who displays good etiquette in his conduct. Eventually, Steerforth turns out to be a false friend and becomes the evidence to reaffirm David's naïve judgment of people. Now the roles are reversed and, instead, it is the disliked Traddles who becomes his lifelong friend. First and foremost, David's misjudgment of people emphasises his lack of experience and he is asked to educate himself and not to commit the same mistakes in the future. To experience the world and gain knowledge, David inevitably associates himself with those experienced characters as well as applying his early mistakes to the more complex situation of embarking on the quest for a suitable love life. Stephen Lutman observes the significance of David as the narrator who has to subdue his desires and educate his "undisciplined heart": contending that "if David knows himself too well, or realises consciously the wider significance of the other characters, he can no longer discover himself and develop" (206). Lutman points out that David develops his identity by depending largely on his circumstances and the people around him.

David's misjudging of his friends is his first episode of trial-and-error to which he finds a solution at the end, yet, it is only a beginning after which he will face another pivotal incident of choosing a wife; choosing between the one he loves and the one who loves him. The trial-anderror of David searching for a wife significantly relates to his early loss of love. David first experience occurs during his childhood when he is forced to lose a perfect love life and make quest for new one. The parallel between the search for love and his pursuit of a career as a writer brings David very close to defining his existence in accordance with the concepts of the Bildungsroman. John Lucas suggests that the story of David Copperfield is characterised by its "feeling of inevitability... of temporal rhythms that cumulatively establish a human life" (169). According to Lucas, the "temporal rhythms" are the inevitable effects of "successive patterns persuade us of the ceaseless process of loss and renewal, change and continuity," (169). Generally, the pattern of his high and low situations emphasizes the temporal rhythm as when David loses his mother and her love but then, when he finds his aunt, his lost love is regained. Once again, his life undergoes a change when David marries Agnes after the death of Dora. All these components of his life contribute to David's story in his fictional autobiography that is full of change and continuity.

Generally speaking, to associate with or to learn from other experienced characters emphasizes David's character as an ordinary person and it is a universal force in stabilizing his being during the time of his growing process. David starts off in his early phase and he admits his childhood inability, even in his recollection of his memories: "I could observe, in little pieces, as it were; but as to making a net of a number of these pieces, and catching anybody in it, that was, as yet beyond me" (21). He states his need to try "to get a better understanding of myself and be a better man" (797). Hillis Miller suggests that "David has, during his childhood of neglect and misuse, been acutely aware in himself of a gap in being" (1958: 157). He is aware of this position of lacking in the knowledge to construct his inner being. David affirms the perspective towards his being of a nobody; "what a blank space I seemed, 
which everybody overlooked, and yet was in everybody's way" (115). He, thus, needs to form for himself an identity and move on to stage of maturity by filling up with "a number of these pieces" of memories by his relation with others. The extent to which Miller has observed David's relationship with others signifies the bridge that connects David to other characters. The association with other characters is significant, as Miller observes, because "David's life, then, is the search for some relationship to another person which will support his life, fill up the emptiness within him, and give him a substantial identity" (1958: 157). There is no possibility for David to exclude himself from Miller's statement on his formation. In general, his intimate relation with characters such as his mother, Peggotty the maid and his aunt Betsey will be discussed because their assertive roles of bringing him up.

Of course, the sign that indicates David's growth is not his mastery of the complexity of language alone but includes his capacity to learn to live with other experienced people. The account of David's association with others can be illustrated through his search for a suitable relationship. Apparently, this search centres on trial-and-error where is David is destined to lose his confidence because he usually commits a mistake before learning to achieve the true experience. David's second lesson of mistaking is when he makes the wrong decision in marrying Dora. They marry when they both are young and naïve, especially Dora, who is merely a spoiled child devoid of the ability "to sustain him and improve him" (489). She is incapable of doing anything and leaves David anxiously concerned about their family. His aunt recognizes this sentimental love as being an ineffective kind of love that will cause "so much misery" and she regards this love as "blind, blind, blind!" (489) affection. David marries Dora, earning his aunt's disapproval, only because he is smitten by her without knowing that love alone can lead him to destruction. Their family situation, as a result of all burdens falling on David alone, worsens, and, what makes things even worse is that, David cannot find any assistance in reading his writing. After the death of Dora, David realises that he still cannot discipline his heart. His achievement in completing his heroic quest seems to have collapsed when this catastrophe occurs. Inevitably, David is tempted by his lack of true love to look for another woman suitable to be his wife. E. K. Brown suggests that the "theme of mistaken love follows and provides the thread for the middle part of the novel" (1990: 787). Eventually, he finds Agnes whose ability is superior to Dora's in many ways; Agnes is capable of doing household chores, and she also has a soaring spirit that assists David in reading and comment on his work. The contrasting roles of these two characters emphasizes to the point that David is in search of a Victorian wife who in every aspect corresponds to the norm of the society and, at the same time, is capable of managing matters in the new world of the Victorian period, for instance, Agnes is able to read and comment on David's work.

Among all the female characters, the central character in David's life is Agnes whose role is significant in his growth and development both to maturity and in terms of his career. David meets Agnes when he goes to attend Dr. Strong's academy and resides with Agnes's father, Mr. Wickfield, until he finishes school. At 
first, he fails to see the goodness in Agnes's nature; whereas Agnes likes him but suppresses her affection for David. She is also supportive of him in whatsoever he does, even in his courtship with Dora. Agnes embodies the qualities which can not be found in Dora. She has the image of an angel as well as that of housekeeper: "She had a little baskettrifle hanging at her side, with keys in it; and looked as staid and as discreet a housekeeper as the old house could have" (217). Even though she realises her insignificance in the eyes of David who sees her as no more than a sister, Agnes is still genuinely concerned about him. For instance, she tries to persuade him to beware the devious character of Steerforth when David indicates an affection towards him even though she knows that David is not pleased with her advice. After the death of his first wife, his aunt advises him to go back to Agnes. He follows her advice and finds out that Agnes has been waiting for him for all that time. This leads to the confusing and reluctant situation when David goes on to marry Agnes and he admits that "There is nothing for it, but to turn back and begin all over again. It was very hard, but I turned back, though with a heavy heart, and began laboriously and methodically to plod over the same tedious ground at a snail's pace" (531). It turns out that Agnes is the opposite of Dora whose understanding of the household or of being a good wife is absent. Regarding David is seeking to discipline his heart, Agnes stands there as representative of a woman of disciplined heart. When David marries her, his life becomes easier, with such convenience in the marriage that it allows him more time to work on his writing and Agnes is able to keep house superbly and assists him in reading his work. The person who approves of his decision to live his life with Agnes is his aunt; all those times she has been observing and seeing what is good and suitable for David but keeps silent out of respect for her nephew's decision. After all of these events occurring to David persuade him of Agnes as the angelic figure that he witnessed during his lodging at her house. And it is this time that the image becomes complete in reality since previously was only an alluring image. Dickens requires that David eventually finds the woman who will help him making progress in his life and his expectations and persuade his aunt that he has achieved the status of a mature Victorian man.

It is through his two marriages that David learns about the true married life he needs to have and, more importantly, to quash his aunt's concerns. Although his disagreement with his aunt's advice signifies his obstinate disobedience, it also implies his failure to see what the experienced person can see. Therefore, his failure in finding the first suitable wife represents David and his immature stage and, as he realises his disastrous decision, he moves forward to the new phase of being the experienced David when married to Agnes. Once David is capable of learning of knowing his heart and committing to the right wife, he undergoes the epiphanic moment of his life. Nevertheless, the crucial element in shaping David's perspective on the real world is his association with other characters, regardless of who they are. In the more realistic world of David, there is another form of love of a mother and a surrogate, in this case, existing to establish a more firm stance for David's existence. This kind of love is similar to the way Dickens employs the juxtaposition of contrasting characters to 
represent how one form is superior to the other and has David cope with his view towards them. Consequently, there is not only the tender love of a mother that David aspires to but also the more complex have for him of his aunt, his surrogate mother.

There is not only the give-and-take kind of love that shapes David's life as the important element of his growth, however, the love that he gains from his mother and the house maid is also another form that he experiences. This is a love considered to be more beneficial to him that, no matter what, he is still able to cultivate it without the cost of the first kind of affection. David reflects a similar attitude towards the two first most important characters of his childhood for the duration of his childhood noting their significance: "Looking back, as I was saying, into the blank of my infancy, the first objects I can remember as standing out by themselves from a confusion of things, are my mother and Peggotty" (13). Among the female characters in his life, David thus regards his innocent childhood love for his mother as the most prominent source to support and sustain him, psychologically and emotionally. Yet Clara Copperfield occupies only a few chapters of the novel. In the same way she represents the short-lived moment of childhood happiness for David when she appears as an angel, in terms of her appearance and her tenderness to him. However, the characteristics of being childlike, fragile and helpless dominate her characterisation in this story, rather than her angelic goodness. David remarks that her vulnerable characteristic makes her comparatively like “"“a wax doll”" (3). It is when his aunt comes to his birth and confronts his mother, that Clara's character is revealed. Much of the conversation between them accentuates the childish helplessness of Clara and confirms Miss Betsey's disapproval of her brother's marriage to David's mother on grounds of her inadequacies and weaknesses. To the marriage of David's parents, she reacts disapprovingly, "David Copperfield all over!...David Copperfield from head to foot!" (6). This suggests the lack of ability in household responsibility of David's mother and how his father pampered her as a child rather than a wife. As predicted, the marriage proves to be unsuccessful and becomes the first hapless incident in David's childhood that is impressed on his memory. As a result, David has never seen a marriage that ends successfully, not even his aunt's marriage, though she exceeds Clara's ability to manage her life. Of these two characters, David can take on the tender love and care from his mother and the strong spirit of his aunt who lives her life independently. This is another example for David to witness that which is different from the love of his mother.

After his childhood ends David begins his next phase with Miss Betsey who disappeared shortly after David's birth. Miss Betsey seems a little strange in her obsession with baby girls and not for a boy like David. The nephew is reunited with his aunt again after he escapes from the blacking factory, desperately searching for her, and is accepted under her guardianship. During his hardships, her peculiar personality is gradually overshadowed by his sole hope to survive from the cruelty of life; and she is the only relative left to him. His life under his aunt's patronage gradually improves since he has the chance to go to school again and make his way to a writing career, eventually; all this is dependent on the provision of Miss Betsey. Not only does 
she offer her nephew financial support, she also provides sound advice as a person who has experienced the failure of married life and has been able to cope with it. She tells him that he should consider the love of Agnes for him after having overlooked it. Her role as a supportive aunt is available in various circumstances and even when she becomes bankrupt she still supports him until she has only one penny left. She is more or less an identical character to Agnes who understands and is capable of managing everything from household matters to business ability. She is the mature Agnes. More significantly, she is the guardian whose role is to provide advice and guide David in the appropriate direction. David's aunt is distinguished in the way that she failed in her marriage and thus she sees, more than Agnes can, through her experience and confidentially advises her nephew. Although she never appears as an angel to David as Agnes does, her kindness towards David and her support regardless of her circumstances all contribute to create the role of a mother surrogate to David. The role in which distinguishes her far more endearing than what she supposes to be in David's first opinion of her.

David depends on these female characters for one reason. They typically give him physical and spiritual nurturing but, for another reason, they provide lessons for him, specifically lessons that shape him into a grown up person. From a mother who is weak and unable to manage things to an aunt whose own married life has failed, to the first wife who resembles his mother in many aspects, and, lastly, the wife, Agnes for whom David cannot find anyone to match; without these females, he would not be capable of learning to see his naïvety. To live forever with his naïvety, would not destroy him spontaneously or take him to a catastrophic end but David has to show his capacity to master life skills not only to survive but to gain more experiences and move away to achieve the phase of the experienced man. $\mathrm{He}$ admits at the blissful moment that "I had advanced in fame and fortune, my domestic joy was perfect, I had been married ten happy years" (844). The triumphant incidents of David Copperfield as the heroic narrator direct to Dickens's success as the author of this story as well.

\section{Conclusion}

Undeniably, the publication of the first edition of David Copperfield resulted in a great change to Dickens's career in the sense that it made the autobiographical novel more appealing via the discussed literary devices. Consequently, sale rates rose higher than his previous publications. Dickens was not the inventor of any of these devices, neither was he the first to use them, but with his capacity to incorporate them with his narrative, they contributed to his fame and David Copperfield's popularity among the readers. The publication of David Copperfield in serialized form created a community who shared the story they read and in this way the community circulated the story of David Copperfield to a wider group of readers, even to a longer period. Also, Dickens' pervasive key concept of inserting plates of illustrations was to entice his readers. He would not have enjoyed his reputation as much as this if he had not modified the Bildung conventional form into his own convenient form as appeared in the novel. Moreover, the role of his narrative importantly attracted his readers in a way that it made the struggles of David more 
empathetic. These literary devices discussed earlier would not have contribute to Dickens's success without his ability to create such enticing narrative to narrate David's life story and David Copperfield would have turned out to be the unread autobiographical novel.

\section{Acknowledgements}

This article is a part of a Master's Thesis entitled The Popularity of Charles Dickens's Novels as Reflected in Their Textual and Media Representations: A Study of David Copperfield, Bleak House and Great Expectations. I would like to express my gratitude to Assist. Prof. Dr. Carina Chotirawe and Assist. Prof. Simon J. P. Wright.

\section{References}

Bandelin, Carl. 1976. David Copperfield: A Third Interesting Penitent. Studies in English Literature, 1500-1900 16.4: 601-611.

Brown, E. K. 1990. The Art of The Crowded Novel. In David Copperfield: A Norton Critical Edition, edited by Jerome H. Buckley, pp. 786794. New York: Norton \& Company.

Cuddon, J. A. 1999. Penguin Dictionary of Literary Terms \& Literary Theory. London: Penguin.

Dickens, Charles. 2008. David Copperfield. Oxford: Oxford University Press.
Eliot, Simon. 2001. The business of Victorian publishing. In Cambridge Companion to the Victorian Novel, edited by Deirdre David, pp. 37-60. Cambridge: Cambridge University Press.

Forster, John. 2004. The Life of Charles Dickens. In $A$ Routledge Literary Sourcebook on Charles Dickens's David Copperfield, edited by Richard J. Dunn, pp. 42- 43. New York: Routledge.

Kincaid, James R. 2004. David Copperfield: Laughter and Point of View. In A Routledge Literary Sourcebook on Charles Dickens's David, pp.49-52. New York: Routledge.

Lutman, Stephen. 1980. Reading Illustrations: Pictures in David Copperfield. In Reading the Victorian novel: Detail into form, edited by Ian Gregor, pp. 68-70. London: Vision press.

Mays, Kelly J. 2005. The Publishing World. In $A$ Companion to the Victorian Novel, edited by Patrick Brantlinger and William B. Thesing, pp. 11-30. Malden; Blackwell Publishing.

Miller, Hillis. 1958. Charles Dickens: The World of his Novels. London: Oxford University Press. 
Sanders, Andrew. 2008.

Introduction. David

Copperfield. By Charles

Dickens. New York:

Oxford University Press. pp.

vii-xx

My friendly waiter and I. (2011).

Retrieved from

http://www.victorianweb.org/

victorian/art/illustration/phiz/d

c/5.html

Somebody turns up. (2011).

Retrieved from

http://www.victorianweb.org/

victorian/art/illustration/phiz/d

$\mathrm{c} / 14 . \mathrm{html}$ 